\title{
Water-Energy-Food Nexus: Background and Perspectives for Brazil and the United States by 2050
}

\author{
Janaina Camile Pasqual ${ }^{1,2}$, Harry Alberto Bollmann ${ }^{2}$ and Christopher Scott ${ }^{3}$ \\ 1. International Center of Renewable Energies/Biogas and International Center of Hydroinformatics (Itaipu Binational), Pontifical \\ Catholic University of Paraná (PUCPR), Curitiba, Paraná 80030180, Brazil \\ 2. Urban Management Program, Pontifical Catholic University of Paraná (PUCPR), Curitiba, Paraná 80215-901, Brazil \\ 3. Udall Center for Studies in Public Policy and School of Geography \& Development, University of Arizona, Tucson, AZ 85719, \\ United States
}

\begin{abstract}
Rapid economic growth, increasing populations and emergent prosperity are driving up demand for energy, water and food, especially in developing countries. In this scenario, the analysis of these three elements has gained the increasing attention globally in research, business and policy spheres. This paper aims to provide an analysis of the perspectives of this nexus for Brazil and the United States, using current and predicted scenario for 2050. Considering the importance of renewable sources of energy to overcome these challenges and diversify the energy matrix in both countries, the paper will also present the biogas potential for both countries, which provides multiple economic, environmental and social benefits, such as electrical, thermal and vehicular energy, high-quality biofertilizer, reduction of odor and pathogenic vectors in the farms, decrease of ground and surface water pollution, promotion of new income for the farmers, reduction of the greenhouse gases emissions, among others.
\end{abstract}

Key words: Water-energy-food nexus, sustainability, renewable energy, biogas.

\section{Introduction}

In a world of increasing urbanization, the efficient management of cities is progressively becoming the focus of international efforts for sustainability. According to the "world urbanization prospects" developed by the United Nations Population Division for the Department of Economic and Social Affairs [1], 100 years ago only $10 \%$ of the world population lived in cities. Today, this proportion represents $54 \%$ and will increase in the coming years, reaching $66 \%$ by 2050. The global urban population grew from about 750 million in 1950 to 3.9 billion in 2014, and continuing population growth is projected to add 2.5 billion people by 2050 [1].

According to United Nations Environment Programme (UNEP) [2], urban areas account for $75 \%$

Corresponding author: Janaina Camile Pasqual, assistant professor, research fields: water-energy-food nexus and biogas. of global waste production, generate $60 \%$ to $80 \%$ of all emissions of greenhouse gases, consume $75 \%$ of natural resources and account for two-thirds of energy consumption, however, they only occupy $3 \%$ of the earth's surface, which represents a considerable concentration of waste and energy consumption with impacts not only in urban but also rural areas.

To accommodate this growing number of people, cities need to become more intelligent, organized and sustainable to reduce poverty, ensure education and health, manage and optimize natural resources to produce the required energy and food, protect the environment and adapt to climate change as well.

One of the most important challenges is the water-energy-food (WEF) nexus, and the three interlinked resource pillars support the existence and survival of human life. Water is an essential natural resource for human life and also an input to the production of food commodities in agricultural fields 
and along the supply chain. Energy is needed to produce and distribute water and food, such as to pump water from underground sources or surface water, propel tractors and irrigation machinery, process and transport goods and provide lighting. And food production is under constant pressure to meet the growing demand, as a result of increase in both population and consumption based on the rising income. The concern is not only about food production, but with the associated waste as well. The three axes of WEF are under constant pressure, as producing food, ensuring water and providing energy for all is a priority.

The UN Water [3] advises that based on the global demand, food production will increase $60 \%$ by 2050 , requiring $45 \%$ more energy and 30\% more water (19\% increase of agricultural water consumption). These numbers show that the expected population increase will generate an asymmetric pressure on the sources of water and energy, for which the ultimate results depend, among other factors, on the technology used in the production of energy and food needed. However, climate change is a phenomenon that we can no longer deny, as its effects are also jeopardizing food, water and energy security. As the earth's temperature continues to rise, we can expect a significant impact on fresh water supplies by the increase of evaporation, causing droughts and melting glacial ice at unprecedented rates. This framework demonstrates that greater efficiency is required in energy production and use of other renewable energy sources that consume the minimal amounts of water.

At this juncture, biogas stands as systemic source of energy generated by the proper treatment of animals, vegetables, human and industrial wastes, transforming environmental liabilities into economic assets through two results: directly through the generation of electric, thermal and vehicular energy (biomethane), and bio-fertilizer; and indirectly with the reduction of greenhouse gas emissions and thereby mitigating global warming.
This study will present the biogas ${ }^{1}$ and livestock production perspectives for Brazil and the United States (US), which are countries with very similar scenarios regarding the opportunities for use of this energy source. And both countries are among the five countries with the largest population and territorial extent [4], leaders in food production, large energy consumers and among the countries with greater availability of water in the world.

\section{WEF Perspectives for 2050 in Brazil and the US}

Water, energy and food are essential for human well-being and sustainable development. Global projections indicate that demand for fresh water, energy and food will increase significantly in the coming decades, driven mainly by population growth, economic development, international trade, urbanization, technological and cultural change, and climate change [5].

In this perspective, the WEF nexus has emerged as a useful concept to explain and address the complex and interrelated nature of these global resources, on which we depend to attain different social, economic and environmental goals. In practical terms, it presents a conceptual approach to better understand and systematically analyze the interactions between the natural environment and human activities, and work towards a more coordinated management of the use of natural resources in all sectors and scales. Effective management of the nexus can help to identify solutions and create synergies, allowing more integrated planning and costs, decision-making, implementation, monitoring and evaluation [5].

\footnotetext{
${ }^{1}$ Biogas is defined as the product gas from anaerobic digestion. It is a biological process, in which microorganisms break down biodegradable material in the absence of oxygen. Biogas is composed mainly of methane (50\% to $70 \%$ ) and carbon dioxide (30\% to $50 \%$ ) with small quantities of particles and other contaminants [6]. According to Metcalf \& Eddy [7], biogas may contain water vapor traces $\left(\mathrm{H}_{2} \mathrm{O}\right.$ vapor), hydrogen sulfide $\left(\mathrm{H}_{2} \mathrm{~S}\right)$, nitrogen $\left(\mathrm{N}_{2}\right)$, oxygen $\left(\mathrm{O}_{2}\right)$, hydrogen $\left(\mathrm{H}_{2}\right)$, carbon monoxide (CO), ammonia $\left(\mathrm{NH}_{3}\right)$ and other gases.
} 
This concept of WEF nexus is today widely addressed and discussed in international institutions, such as UNESCO, FAO, IEA, OLADE and OECD. It is becoming increasingly prominent on policy makers' agendas, notably in relation to the post 2015 development agenda [5]. The sustainable development goals currently being pursued by the United Nations are at the center of this agenda.

According to Scott et al. [8], institutional support for the WEF nexus gained significant momentum via the Bonn Freshwater Conference, the Bonn 2011 Nexus Conference, the Stockholm World Water Week, the United Nations Economic Commission for Europe, and the now well established "Water, Energy, and Food Security Nexus Resource Platform”.

The discussion about WEF nexus forces us to think about the impact that a decision in one sector can have not only in that sector, but also on others. By Anticipating potential trade-offs and synergies, it is possible to design, evaluate and prioritize response options that are feasible in different sectors. Recognizing these synergies and balance, the trade-offs is essential to jointly ensure water, energy and food security [9].
According to International Renewable Energy Agency (IRENA) [10], renewable energy technologies, for example, can address some of the trade-offs between WEF, bring considerable benefits in all three sectors and can allay competition by providing energy services using less resource-intensive processes and technologies, compared to conventional energy technologies.

Fig. 1 describes Hoff's nexus framework that integrates global trends (drivers) with action fields, considering the available water resources as the core point (at the center) [11].

As seen in Fig. 1, urbanization, population growth and climate change are the top three global-scale phenomena that influence water availability, thus affecting the water and food supply systems for people and threatening the production of energy as well, especially in the countries that are highly dependent on water resources in its generation.

In this section, the WEF perspectives for Brazil and the US by 2050 will be presented. It is important to state that both countries have very similar scenarios, as presented in Table 1.

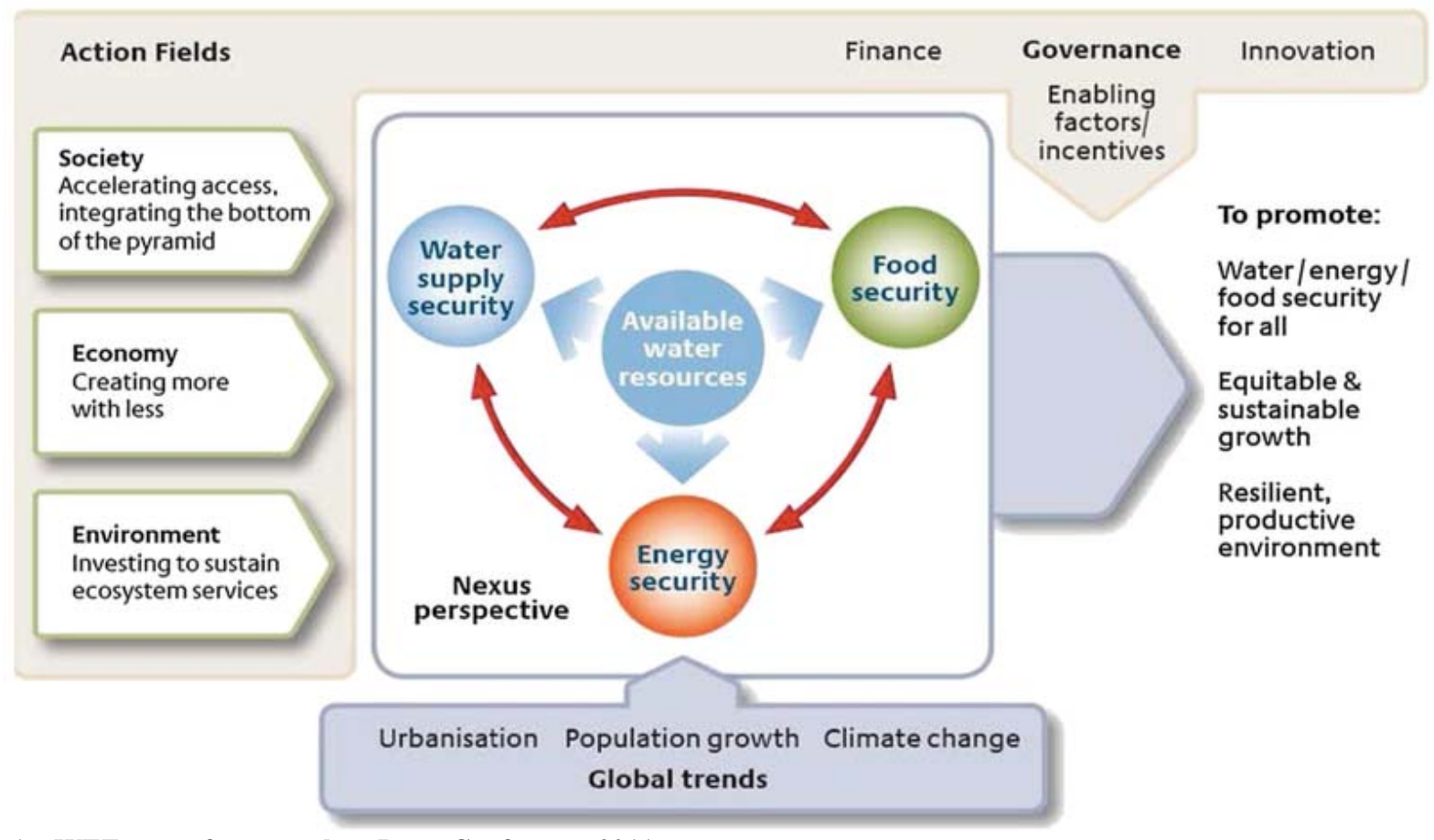

Fig. 1 WEF nexus framework at Bonn Conference 2011.

Source: Hoff, 2011 [11]. 
Table 1 Brazil and the US position compared to other countries.

\begin{tabular}{|c|c|c|}
\hline \multirow{2}{*}{ Description } & \multicolumn{2}{|c|}{ Rank } \\
\hline & Brazil & US \\
\hline Population $^{1}$ & 5th & 3rd \\
\hline Territorial extension ${ }^{1}$ & 5th & 3rd \\
\hline Water availability $^{2}$ & $1 \mathrm{st}$ & 3rd \\
\hline Energy consumption $^{3}$ & 9th & 2nd \\
\hline Food production $^{4}$ & 4th & 3rd \\
\hline
\end{tabular}

\subsection{Brazil}

\subsubsection{Water}

Brazil is privileged in the availability of water resources, because it has $12 \%$ of all surface fresh water in the world $\left(180,000 \mathrm{~m}^{3} / \mathrm{s}\right)$, twice of that in Australia and Oceania, 42\% higher than that in Europe and 25\% higher than that in mainland Africa [14].

Water availability per person in Brazil is 43,000 $\mathrm{m}^{3}$ /person/year, 19 times higher than the minimum established by the United Nations [15]. Despite this favorable scenario, there is an uneven spatial distribution of water resources in Brazil, because about $80 \%$ of its availability is concentrated in the Amazon region, where the fewest people live (less than $5 \%$ of the Brazilian population) and the reduced consumption demands per capita is only $0.3 \%$ of the local water resources [14].

The water consumption in Brazil is 166.3 L/capita/day, above the level recommended by the World Health Organization (WHO), which is $110 \mathrm{~L}$. This consumption has increased in recent years. In 2008, every Brazilian consumed an average of 151.2 L, increasing to $159 \mathrm{~L}$ in 2010 and reaching $166.3 \mathrm{~L}$ in 2014-a 10\% increase in six years. It should be noted that part of this high consumption (37\% in 2013) is due to losses in the water distribution system, which has been reduced tentatively in recent years [16].

The available water is consumed mostly for irrigation activities (75\%), followed by livestock supply (9\%), urban supply (8\%), industry (6\%) and rural supply (2\%), as shown in Fig. 2 [17].

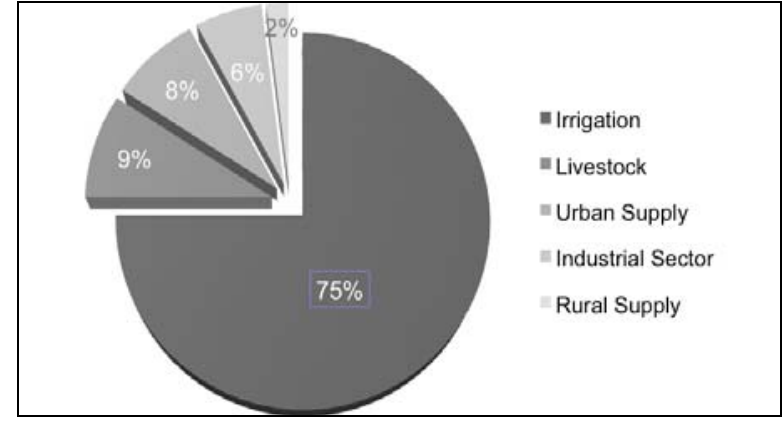

Fig. 2 Water consumption by sector in Brazil.

Source: adapted from Brazilian National Water Agency [17].

According to FAO [18], the high consumption of water for irrigation is because that Brazil is among the four countries with the greatest potential area for this activity, although only a small part is used. The great potential is due both to the territorial extension on the set of physical and climatic factors favorable to the development of the activity. The Brazilian National Water Agency [17] estimates that between 2005 and 2025, average demand for water supply for the urban population will grow $28 \%$.

\subsubsection{Energy}

Brazil has one of the most privileged energy matrixes in the world, with $41.2 \%$ of the domestic energy supply (DES) ${ }^{2}$ arising from renewable sources, while the world average is $13.5 \%$ and in developed countries only $9.4 \%$ [19].

The Brazilian energy model remains heavily dependent on hydroelectricity, which represents a large current and future dependence of water available in the country. About $64 \%$ of the country's electricity is from hydroelectric generation, and more than $25 \%$ of this generation (about $75 \mathrm{TWh} /$ year) comes from a single hydropower generation source, the massive Itaipu Binational Facility, located between Brazil and Paraguay.

According to the national energy balance [19], the share of renewable sources in electricity production was $76 \%$, as presented in Fig. 3.

\footnotetext{
${ }^{2}$ DES is also known as an energy matrix, which is all the energy available in order to be transformed, distributed and consumed in production processes in Brazil.
} 


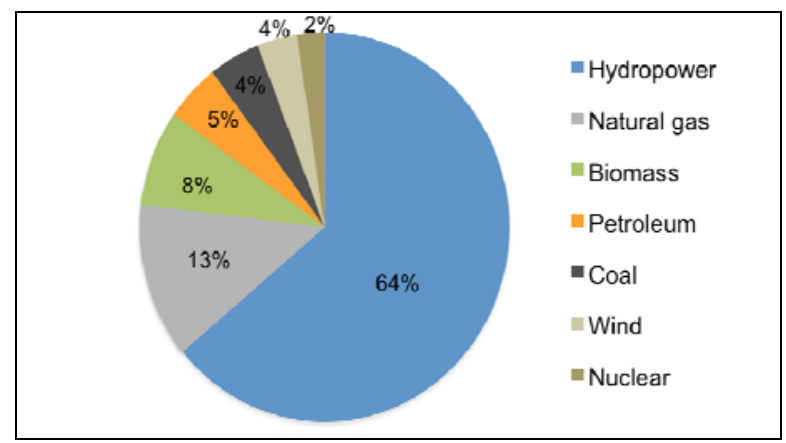

Fig. 3 Brazilian electric matrix.

Source: adapted from National Energy Research Company (EPE) [19].

The sector that consumes the most energy is the industrial (32.5\%), followed by transport (32.2\%), energy sector (10.7\%), housing (9.6\%), services (4.8\%) and agriculture and livestock $(4.4 \%)^{3}$ [19].

The National Energy Plan 2050 (PNE 2050) announces the prediction of population increase by 25 million from 2013-2050 and a total energy demand increase of more than twice, mainly in the commercial sector. From 2005 to 2030 is expected to increase $3.7 \%$ per year in energy demand, and the share of renewable sources will be increasingly significant in the Brazilian energy matrix, corresponding to $45 \%$ of all energy consumed in the country [20].

Regarding $\mathrm{CO}_{2}$ emissions in the energy sector, to produce and consume energy, each Brazilian (2.3 ton $\mathrm{CO}_{2} /$ capita/year) emits on average seven times less than that in the US (16.2 ton $\mathrm{CO}_{2} /$ capita/year) and three times less than a European or Chinese (6.6 ton $\mathrm{CO}_{2} /$ capita/year) [19].

\subsubsection{Food}

Brazil is the fourth country in the world in food production, behind China, India and the US. It is the second food exporting country, behind the US. Agribusiness accounts for seven of the ten most exported items by Brazil, mainly soybean, coffee, orange, beef meat and swine meat [18].

Taking into account the population increase projections in the country of $28 \%$ by 2050 (Table 2), it is possible to affirm that food production will be a key

\footnotetext{
${ }^{3}$ Non-energy uses account for $5.8 \%$.
}

Table 2 Population projections by 2050 in Brazil.

\begin{tabular}{llll}
\hline \multirow{2}{*}{ Rank } & \multicolumn{3}{c}{ Population (millions) } \\
\cline { 2 - 4 } & 2010 & 2030 & 2050 \\
\hline 5th position & 198,982 & 236,480 & 254,085 \\
\hline Source: adapted from Ministry of Agriculture [20]. \\
factor for the country development.
\end{tabular}

According to FAO [5], Brazil will need to increase its food production capacity by $40 \%$ to meet worldwide demand. For these projections, the country will need to make intensive investment in technology and create a new way of thinking about food production. One of the greatest advantages of Brazil, besides water availability, is the land availability for food production. Currently, the country uses only $14 \%$ of its productive land (65 million ha) and the potential is 385 million ha [20].

\section{$2.2 U S$}

\subsubsection{Water}

Water availability in the US is 10,000 $\mathrm{m}^{3} /$ capita/year. According to the Central Intelligence Agency [12], US is the third country with the highest water availability $\left(3,069 \mathrm{~km}^{3} /\right.$ capita renewable internal freshwater), behind Brazil $\left(8,233 \mathrm{~km}^{3}\right)$ and Russia $\left(4,508 \mathrm{~km}^{3}\right)$.

The water consumption is about $378 \mathrm{~L} /$ capita/day, above the $110 \mathrm{~L}$ recommended by United Nations. This consumption has increased over the years. In 1950, each American consumed an average of $150 \mathrm{~L}$, increasing to $303 \mathrm{~L}$ in $1970,326 \mathrm{~L}$ in 2000 and reaching $378 \mathrm{~L}$ in 2010. Considering the period from 2000 to 2010 , there was a $16 \%$ increase in consumption [12].

The available water is consumed predominantly by thermoelectrics (45\%), irrigation (32\%), public supply (12\%) and industrial sector (4\%), as shown in Fig. 4.

\subsubsection{Energy}

The US is the second largest energy consumer in the world, behind China. Its energy matrix remains heavily dependent on fossil fuels (35\% petroleum, 28\% natural gas, $18 \%$ coal and $8 \%$ nuclear electric power), 

and the United States by 2050

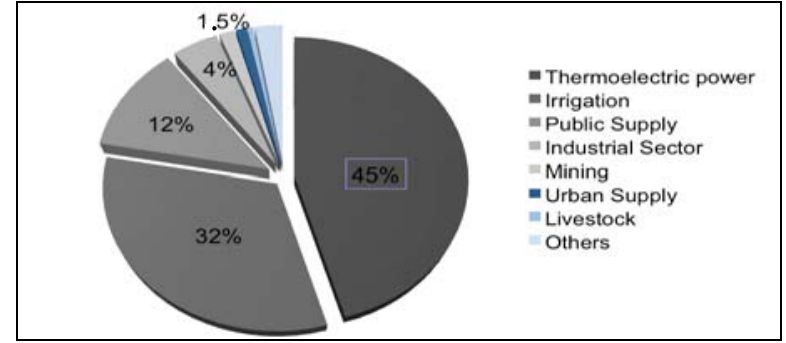

Fig. 4 Water consumption by sector in the US. Source: adapted from US Geological Survey [15].

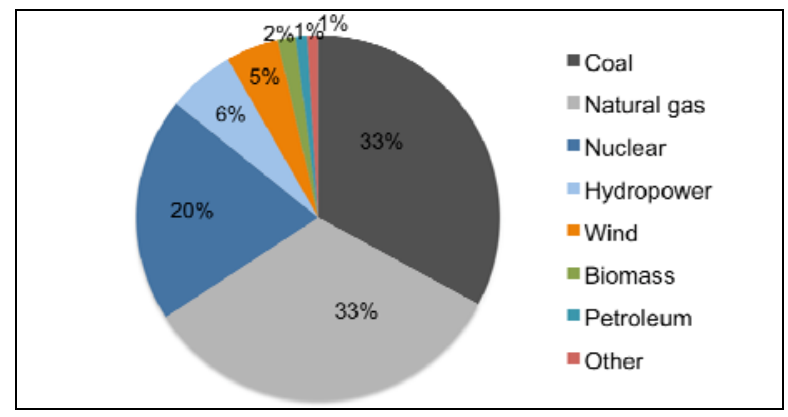

Fig. 5 The US electric matrix.

Source: EIA, 2015 [13].

Table 3 Population projections by 2050 in the US.

\begin{tabular}{lllll}
\hline \multirow{2}{*}{ Rank } & \multicolumn{4}{c}{ Population (millions) } \\
\cline { 2 - 5 } & 2010 & \multicolumn{2}{c}{2030} & 2050 \\
\hline 3rd position & 314,692 & \multicolumn{2}{c}{366,187} & 402,415 \\
\hline Source: adapted from & the & US & Energy & Information \\
Administration [21]. & & &
\end{tabular}

and only $10 \%$ of the energy is generated through renewable sources.

According to the US Energy Information Administration (EIA) [21], about $87 \%$ of the electricity generated is from fossil fuels (coal, natural gas, and petroleum) and only $13 \%$ from renewable sources, as presented in Fig. 5.

The sector that consumes the most energy is electric power (39\%), followed by transportation (27\%), industrial (22\%) and residential and commercial (12\%).

Despite population growth in the coming years, EIA states energy consumption projections for 2040 by modest grow rate, averaging $0.3 \%$ per year from 2013 through 2040. A marginal decrease of energy consumption in transportation sector contrasts with growth in most other sectors. Decreases in energy consumption tend to result from the adoption of more energy-efficient technologies and existing policies that promote increased energy efficiency [20].

The rising long-term natural gas prices, the high capital costs of new coal and nuclear generation capacity, state-level policies, and cost reductions for renewable generation will stimulate the electricity demand growth for renewable. Renewable electricity generation will increase by $72 \%$ from 2013 to 2040, accounting for more than one-third of new generation capacity. And the share of renewables in total generation will grow from $13 \%$ in 2013 to $18 \%$ in 2040 [21].

Biomass generation is projected to increase by an average of 3.1\% per year, led by co-firing ${ }^{4}$ at existing coal plants through about 2030. After that period, new dedicated biomass plants account for most of the growth in generation from biomass energy sources.

Regarding $\mathrm{CO}_{2}$ emissions in the energy sector, in 2013, the country produced 5.405 million metric tons (Mt). According to the predictions of the EIA [22], $\mathrm{CO}_{2}$ emissions will increase by 144 million Mt (2.7\%) in the period 2013 to 2040, amounting to 5.549 million Mt/year.

\subsubsection{Food}

The US is the third country in the world in food production. It is the first food exporting country, and the main commodities are citrus fruits, corn, soybeans, peanuts, wheat, cotton, chicken, beef and pork [18].

Its agricultural industry is one of the largest in world and holds the world's productivity index, with the use of modern cultivation techniques and machinery.

The population increase projection for the US by 2050 is of $28 \%$, the same index of Brazil. It will be the country with the third largest population in the world, with 402,415 million people, which means that more water, energy and food for the country's development will be necessary, as presented in Table 3.

As similar to Brazil, the US has a great potential for

\footnotetext{
${ }^{4}$ Co-firing is a low-cost option for efficiently and cleanly converting biomass to electricity by adding biomass as a partial substitute fuel in high-efficiency coal boilers.
} 
food production increase, as the country currently uses $48 \%$ of its productive land (190 million ha) and the potential is of 390 million Ha [22].

\subsection{Reflections about WEF Nexus for Brazil and the} US

After analyzing the water, energy and food predictions for Brazil and the US by 2050, it is possible to affirm that WEF nexus can provide a framework for systematically assessing cross-sectorial interactions [23]. Moreover, it is possible to make some reflections about the renewable energy scenario and the potential for biogas. Table 4 presents the compiled data about both countries.

It is possible to state that the abundant water availability for hydroelectric power is beneficial for Brazil, as it reduces the country's overall generation costs when compared to countries with more diverse supply mixes.

Hydropower is also more environmentally friendly in many respects than most thermal generation [10].
Nonetheless, this high dependence on hydropower makes Brazil intensely vulnerable to supply shortages in low rainfall years, especially when consumer and industrial demand is robust and increasing.

This strengthens the importance of a diversified and renewable energy matrix, in which biogas can be protagonist. Experts have warned for years that Brazil's electricity supply mix is inherently volatile and that it needs to diversify its sources to avoid major seasonal supply shortages. The 2001 and 2014 water crises confirmed Brazil's perennial susceptibility to drought caused by an excessive dependence on hydropower and the country's low diversified energy matrix. That scenario proposed an enormous opportunity to the developers of non-hydropower plants to expand and diversify power generation.

Besides receiving severe criticism about fossil fuels uses and not being as renewable as Brazil's, the energy matrix of the US is more diversified, not depending of only one source of energy.

In this context, for the US it would be very appropriate

Table 4 Compiled data about WEF scenarios for Brazil and the US.

\begin{tabular}{|c|c|c|}
\hline WEF & Brazil & USA \\
\hline Water availability & 43,000 m³/capita/year & $10,000 \mathrm{~m}^{3} /$ capita/year \\
\hline Water distribution & $\begin{array}{l}\text { Uneven: } 80 \% \text { of water is in Amazon region with } \\
\text { less than } 5 \% \text { of the Brazilian population }\end{array}$ & Uneven \\
\hline Water consumption & Average 166 L/capita/day & Average 378 L/capita/day \\
\hline Main water use & $\begin{array}{l}\text { Irrigation } 75 \% \\
\text { Livestock } 9 \% \\
\text { Urban supply } 8 \% \\
\text { Industry supply } 6 \% \\
\text { Rural use } 2 \%\end{array}$ & $\begin{array}{l}\text { Thermoelectric plants } 45 \% \\
\text { Irrigation } 32 \% \\
\text { Public uses } 12 \% \\
\text { Industry supply } 4 \% \\
\text { Mining } 1.5 \% \\
\text { Urban supply } 1 \% \\
\text { Livestock } 0.6 \% \\
\text { Others } 2.7 \% \\
\end{array}$ \\
\hline $\begin{array}{l}\text { Energy from renewable } \\
\text { sources }\end{array}$ & $\begin{array}{l}\text { Total } 76 \%: \\
\text { Hydro 64\% } \\
\text { Biomass } 8 \% \\
\text { Wind } 4 \% \\
\end{array}$ & $\begin{array}{l}\text { Total 13\%: } \\
\text { Hydro 6\% } \\
\text { Biomass 2\% } \\
\text { Wind 5\% } \\
\end{array}$ \\
\hline Vulnerability & $\begin{array}{l}\text { Highly dependent of hydroelectricity and highly } \\
\text { vulnerable to climate change and to the increase of } \\
\text { water consumption, because legislation prioritizes } \\
\text { human consumption }\end{array}$ & $\begin{array}{l}\text { Better distribution among energy sources and } \\
\text { less dependent of one. The problem is the } \\
\text { massive use of oil and coal with impacts on } \\
\text { greenhouse effects }\end{array}$ \\
\hline CO2 per capita & 2.3 ton $\mathrm{CO}_{2} /$ capita/year & 16.2 ton $\mathrm{CO}_{2} /$ capita/year \\
\hline Food & $\begin{array}{l}\text { Great potential for food production (land } \\
\text { available, water available and good climate). } \\
\text { Production will increase in } 40 \% \text { up to 2050: need } \\
\text { investments in technology and innovation for } \\
\text { production }\end{array}$ & $\begin{array}{l}\text { Great potential to food production (land and } \\
\text { water available and good technology) }\end{array}$ \\
\hline
\end{tabular}

Source: adapted from US Geological Survey [15], EIA [13] and National Energy Research Company [19]. 
to invest in renewable sources of energy that could be installed in a dispersed and interconnected way, supplying local and regional demands. For Brazil, it would also be important to keep a high level of renewability of its energy matrix, instead of depending primarily on hydroelectricity. And for both scenarios, the biogas would be a suitable possibility, attending to environment, economic and social aspects.

The community/collective energy generation is a strategic model to generate rural energy in a decentralized manner, reducing the dependence on fossil fuels and the vulnerability of the energy generation sector in both countries.

A pilot plant will be presented in the following. Besides reducing water pollution through the appropriate waste treatment, these projects also would diminish the greenhouse gases emissions, keeping the low Brazilian emissions levels and reducing the US emissions.

\section{Agribusiness Biogas Perspectives for Brazil and the US}

As presented in the previous section, the projections for world population growth will increase the global demand for water, energy and food, generating impacts on the environment if not properly managed.

Brazil and the US are among the largest producers of food in the world, with growth projections for the coming years, which certainly represent a great potential for biogas generation through the waste of these productions. The close relationship between biofuels and water, energy and food security encapsulates many of the WEF nexus issues.

Biogas is the source that most resembles the hydraulic power [24], as it can be stored and dispatched continuously, unlike solar and wind sources are characterized by intermittency in networks, and can be further purified and transformed into biomethane, which resembles natural gas and can be used to replace fossil fuels for sustainable urban mobility.
In addition to promoting these environmental and economic benefits, biogas promotes local social development, since the process for its production constitutes and sustains a relatively complex supply chain, requiring local skilled labor, technical and scientific support, training the local population and the management of processes to obtain biogas and biomethane.

\subsection{Biogas Perspectives for Brazil}

The agribusiness biogas potential in Brazil is very meaningful, as this activity represents $23 \%$ of the national gross domestic product (GDP). In 2015, while the total national GDP contracted 3.8\%, the biogas sector grew 1.8\% compared to 2014 (0.4\%). In the same year, the share of agribusiness in the trade balance was recorded to account for $46.2 \%$ of all exports [25].

This scenario represents a great opportunity for biogas uses, as the rural proprieties can use their wastes to generate energy, biofertilizer and avoid water pollution.

The Brazilian Energy Research Company (EPE) analyzed the agribusiness sector wastes and concluded that the country can generate about 237 million tons on a dry basis in agriculture, which means an energy potential of 38,189 thousand tons of oil equivalent ${ }^{5}$, and 238 million tons of animal wastes in the livestock production, which represents 10,543 thousand tons ${ }^{6}$. This represents an energy production of 17,784 MW/year and $17.6 \mathrm{Mm}^{3} /$ day of biomethane [25]. Considering the per capita energy consumption in Brazil of $213 \mathrm{kWh} / \mathrm{month}^{7}$, it is possible to power 6,957 people per month with this biogas energy.

It is important to ponder that the potential presented considers only the portion that can be removed from

\footnotetext{
${ }^{5} 70 \%$ of the potential is in corn and soybeans wastes, the two largest grain crops in the country.

${ }^{6} 62.5 \%$ of the potential is chicken wastes. It was only considered confined herds.

7 The per capita energy consumption not only includes residential consumption and public lighting, but the entire consumption of the city (including industry, commerce, etc.).
} 
the field. Thus, there is the need for adequacy and development technologies to collect these wastes in the field and to improve the logistics chain in the rural areas.

In Brazil, there are many initiatives including biogas and biomethane in the rural properties. Two of them, located in South Brazil, will be briefly presented: Ajuricaba Agroenergy Condominium for family agriculture and Haacke Chicken Farm. These initiatives are being developed by Itaipu Binational, the world's largest hydroelectric power generation company, situated on the border between Parana State in Brazil and Paraguay.

3.1.1 Ajuricaba Agroenergy Condominium for Family Agriculture

The condominium is composed by 33 small properties, with areas between 10 ha and 20 ha, which produce soybean, corn, wheat, 1,072 cattle and 3,082 pigs, generating approximately $821 \mathrm{~m}^{3}$ of biogas per day and 16 thousand tons of waste/year.

One digester was installed in each property for waste degradation, and the biogas can be used directly in the properties to cook food or to heat water for cleaning dairy utensils, or can be sent by pipeline (25 $\mathrm{km})$ to a micro-thermal station. The biogas generated can be converted into electrical energy, thermal energy (grain dryer) and vehicle power. Currently, the electric generation is of $350 \mathrm{kWh} /$ day [26].

It is important to highlight that the electricity generated by the biogas should be seen as complementary and not exclude the current system, i.e., the generator does not need to be disconnected from the electrical system, and instead, use the energy produced in the own property, and when necessary, consumes from the local utility.

In addition to promoting environmental and economic benefits to these farmers, the project is promoting local social development, since the process for biogas production constitutes and sustains a relatively complex supply chain, requiring local skilled labor, technical and scientific support, and environmental awareness in local community.

\subsubsection{Haacke Chicken Farm}

Haacke Farm has 80,000 laying hens and 750 cattle, producing a total of $1,000 \mathrm{~m}^{3}$ of biogas per day, as a result of the manure generated and treated into an anaerobic system. The biogas generated in the digesters is a gaseous fuel with high energy potential; however, it is a raw material, not a product. To get to the real and qualified biogas fuel potential, it is necessary to refine it in different intensities to obtain the biomethane, which was considered a fuel product whose potential can match the one from natural gas.

For this purpose, a refinery was installed in the property to perform the removal or reduction of compounds, such as $\mathrm{H}_{2} \mathrm{~S}, \mathrm{CO}_{2}$ and water vapor, promoting the increase of the calorific value and raising the concentration of methane on the biogas.

Through the refining, 98\% of biogas is converted into biomethane and achieves the characteristics of compressed natural gas (CNG), being able to meet the regulations of the National Agency of Petroleum (ANP) [27].

After the refining, the bio-methane is compressed into cylinders for transportation, a process carried out in two interconnected cylinders baskets with $280 \mathrm{~m}^{3}$ capacity each. For the supply of biomethane, Itaipu installed one dispenser, which aims to transfer the biomethane contained in the baskets to the vehicles in a safe and controlled way. It has built a biomethane station inside the Itaipu area, as shown in Fig. 6.

The experimental results were made in partnership with Scania, in one of the most modern buses in the world (Euro 6), used to transport employees and visitors in Itaipu Binational and in some cars that originally operated with CNG.

In 19 days of monitored tests, the bus carried 3,250 passengers in Itaipu complex, ran $3,000 \mathrm{~km}$ and consumed $745.58 \mathrm{~m}^{3}$ of biomethane. The average yield was $1.90 \mathrm{~km} / \mathrm{m}^{3}$, being equivalent to the consumption of CNG and $40 \%$ more efficient than diesel. In addition, it avoided the emission of 100 tons of $\mathrm{CO}_{2}$ equivalent, 


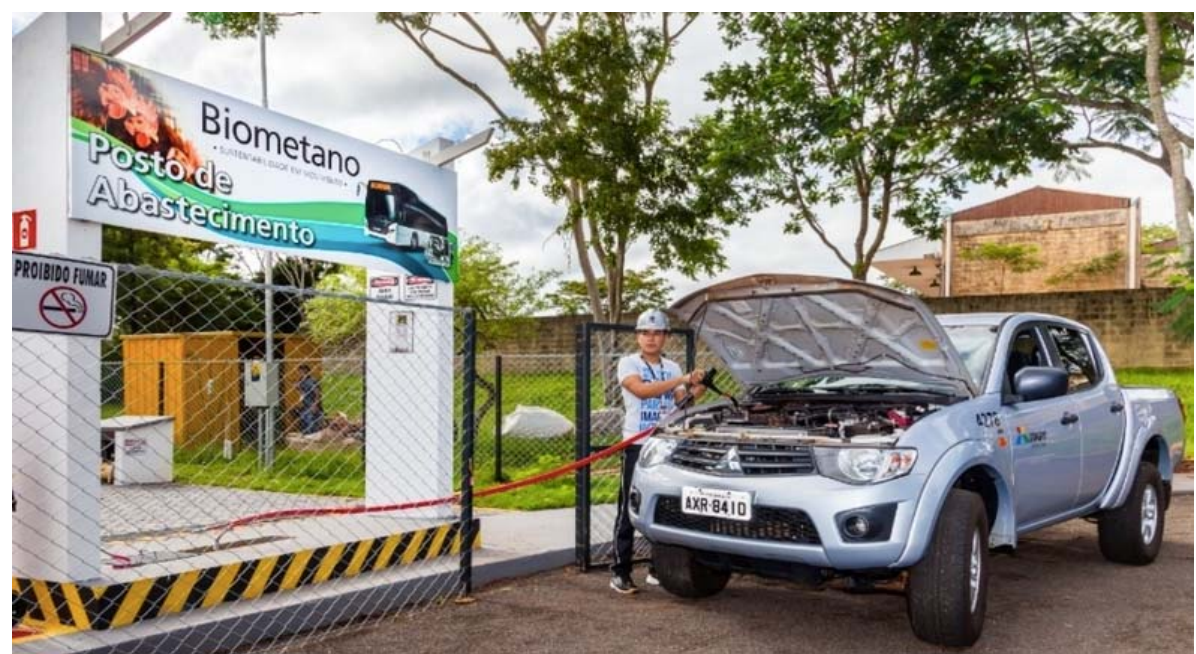

Fig. 6 Biomethane station.

Source: CIBiogas, 2016 [26].

a 70\% reduction if compared to a diesel-powered bus. Another important advantage is the cost. The biomethane cost per kilometer is $56 \%$ lower than the diesel cost [26].

The substitution of biogas, an energy source derived from biological feedstock, for fossil natural gas can mitigate the build-up of greenhouse gases in the atmosphere [28]. This makes biogas an attractive renewable source of energy in a carbon-constrained future.

These projects demonstrate that biogas and biomethane can help to diversify the energy matrix in a positive way, removing environmental liabilities that highly pollute water resources and the air, converting them into energy assets to rural and urban mobility and providing best quality of life to people who live in these areas. Furthermore, it demonstrates that water, energy and food are interlinked and can bring benefits if managed together.

Studies show that long-term use of biomass energy is more advantageous than employing the land for carbon sink forests [29]. These biogas projects prove that it is possible to increase the participation of sustainable energy in relation to the total electricity consumption in Brazil, replacing the construction of power plants using fossil fuels by renewable ones.

Certainly policy incentives are necessary in the country to increase biogas use and stimulate more projects.

\subsection{Biogas Perspectives for the US}

The US is one of the world leaders in agribusiness sector: the first in corn, soybean, wheat and chicken production, the third in swine production and the fourth in beef production [18].

This scenario indicates a good opportunity for biogas generation. Studies show that the biogas potential in the US, only with animal wastes, can generate 8.8 billion $\mathrm{kWh}$ of electricity, enough to power 894,000 homes [24].

In 2015, anaerobic digesters on livestock farms reduced GHG emissions by 3.0 million metric tons of $\mathrm{CO}_{2}$ equivalent (MT $\left.\mathrm{CO}_{2} \mathrm{e}\right) ; 2.46$ million $\mathrm{MT} \mathrm{CO}_{2} \mathrm{e}$

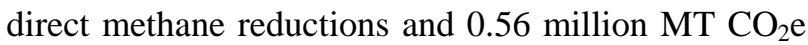
emissions avoided. In the same year, energy generation from anaerobic digesters on livestock farms was approximately 981 million kWh equivalent [30].

Since 2000, anaerobic digesters on livestock farms have reduced direct and indirect emissions by 20.85 million $\mathrm{MT} \mathrm{CO}_{2} \mathrm{e}$.

Taking into account that $60 \%$ of livestock water use is from groundwater [15], biogas can be a good alternative to treat the wastes and avoid water 
pollution, generate income and reduce energy costs with water pumping, besides other benefits mentioned before.

Besides its benefits, biogas projects need more incentives and public policies in the country. In particular, trade-offs between pipeline biogas supply and onsite electricity generation are important to consider. The real rate and extent of biogas market diffusion will depend on how electric power and gas markets evolve, and on the specific design and application of future policy initiatives used to favor one product over the other. Successes and failures of other countries' policy incentives for biogas expansion should be considered [28].

\section{Conclusions}

Taking into account the projected population growth in the coming years, the supply of water, energy and food are under constant pressure. These three elements are indispensable to the social and economic development of a country, which is why their joint analysis is so important. It is increasingly clear that effective and sustainable solutions to the challenge of global climate change will demand greater understanding of the linkages and inter-dependencies among these three elements.

Considering the importance of renewable sources of energy to overcome these challenges and diversify the energy matrix, this study analyzed the biogas potential for Brazil and the US. It is concluded that both countries have great potential for biogas usage, as they are among the five countries with the largest population in the world and territorial extent (fifth and third place, respectively), are leaders in food production (fourth and third place, respectively), large energy consumers and among the countries with greater availability of water in the world (first and second position).

The agribusiness sector is very representative in both countries, providing good conditions for biogas generation. Biogas usage can provide multiple economic, environmental and social benefits, such as electrical, thermal and vehicular energy, high-quality biofertilizer, reduction of odor and pathogenic vectors in the farms, decrease of ground and surface water pollution, promotion of new income for the farmers, reduction the greenhouse gases emissions, among others. In this scenario, Brazil and the US can use the agribusiness production to reduce methane emissions and get results in the fight against climate change.

Although both countries have several biogas projects implemented, policy incentives are necessary to increase its use, including promoting biogas utilization through new programs, fostering investment in biogas systems, strengthening markets for biogas systems and improving communication and coordination.

WEF nexus analysis is very important for these projects, considering water, food and energy availability, where competing demands for water can sharpen the trade-offs and opportunity costs of water use across agriculture (food production), electricity generation and environmental needs.

The expansion of renewable energies, such as biogas, can help to diversify the energy matrix in a positive way and mitigate climate change impacts, by greenhouses gases emissions reduction.

\section{Acknowledgments}

The authors are grateful for International Center of Renewable Energies-Biogas and International Center of Hidroinformatics for the data availability, Pontifical Catholic University of Paraná and Coordination for the Improvement of Higher Education Personnel (CAPES) for the financial support and the University of Arizona for collaboration and technical support.

\section{References}

[1] United Nations Department of Economic and Social Affairs. 2014. "World Urbanization Prospects.” Accessed July 09, 2016. https://esa.un.org/unpd/wup/Publications/Files/WUP2014 -Highlights.pdf.

[2] United Nations Environment Programme (UNEP). 2011. “Towards a Green Economy: Pathways Sustainable 

and the United States by 2050

Development and Poverty Eradication.” Accessed August 10, 2016. http://www.unep.org/greeneconomy/Portals/ 88/documents/ger/Green_Economy_Full_report_pt.pdf.

[3] United Nations Water. 2015. "Water for Food.” Accessed July 07, 2016. http://www.unwater.org/fileadmin/ user_upload/unwater_new/docs/water_for_food.pdf.

[4] World Bank. 2014. "Population 2014.” Accessed July 20, 2016. http://databank.worldbank.org/data/download/ POP.pdf.

[5] Food and Agriculture Organization of the United Nations (FAO). 2014. "The Water-Energy-Food Nexus: A New Approach in Support of Food Security and Sustainable Agriculture.” Accessed May 20, 2016. http://www.fao.org/nr/water/docs/FAO_nexus_concept.p df.

[6] National Renewable Laboratory (NREL). 2013. "Biogas Potential in the United States.” Accessed June 09, 2016. http://www.nrel.gov/docs/fy14osti/60178.pdf.

[7] Metcalf \& Eddy, Inc.. 2003. Wastewater Engineering: Treatment Disposal Reuse, 4th ed. New York: McGraw-Hill.

[8] Scott, C. A., Kurian, M., and Wescoat, J. L. 2015. "The Water-Energy-Food Nexus: Enhancing Adaptive Capacity to Complex Global Challenges.” In Governing the Nexus, edited by Kurian, M., and Ardakanian, R. Switzerland: Springer International Publishing.

[9] United Nations Water. 2015. "World Water Development Report (WWDR).” Accessed May 11, 2016. http://www.unesco.org/new/en/natural-sciences/environm ent/water/wwap/wwdr/.

[10] International Renewable Energy Agency (IRENA). 2015. "Renewable Energy in the Water, Energy, Food Nexus." Accessed June 06, 2016. http://www.irena.org/DocumentDownloads/Publications/I RENA_Water_Energy_Food_Nexus_2015.pdf.

[11] Hoff, H. 2011. Understanding the Nexus: Background Paper for the Bonn 2011 Conference on the Water, Energy and Food Security Nexus. Stockholm, Sweden: Stockholm Environment Institute (SEI).

[12] Central Intelligence Agency. 2011. "Total Renewable Water Resources.” Accessed May 05, 2016. https://www.cia.gov/library/publications/the-world-factbo ok/fields/2201.html.

[13] US Energy Information Administration (EIA). 2015. "USA Energy in Brief." Accessed July 28, 2016. http://www.eia.gov/energy_in_brief/article/major_energy _sources_and_users.cfm.

[14] Brazil Ministry of the Environment. 2015. "Water Availability in Brazil.” Accessed July 23, 2016. http://www.mma.gov.br/agua.

[15] US Geological Survey. 2014. "Hydrological Regions.” Accessed May 07, 2016. http://nhd.usgs.gov/wbd.html.
[16] Brazilian Association of Sanitary and Environmental Engineering. 2014. "Losses in Water Supply Systems.” Accessed August 24, 2016. http://abes-sp.org.br/arquivos/perdas.pdf.

[17] Brazilian National Water Agency (ANA). 2015. "Framework of Water Resources in Brazil." Accessed August 11, 2016. http://www3.snirh.gov.br/portal/snirh/ centrais-de-conteudos/conjuntura-dos-recursos-hidricos/c onjuntura_informe_2015.pdf.

[18] Food and Agriculture Organization of the United Nations (FAO). 2012. "FAO’s Information System on Water and Agriculture.” Accessed May 20, 2016. http://www.fao.org/nr/water/aquastat/data/.

[19] Energy Research Company (EPE). 2016. "National Energy Balance 2016.” Accessed August 10, 2016. https://ben.epe.gov.br/downloads/S\%C3\%ADntese\%20d o\%20Relatório\%20Final_2016_Web.pdf.

[20] Brazil Ministry of Agriculture. 2015. “The World in 2050 and Challenges and Opportunities in Brazilian Agribusiness.” Accessed May 24, 2016. http://www.agricultura.gov.br/arq_editor/file/camaras_te maticas/Cooperativismo/5RO/App_Mundo_Cooperativis mo.pdf.

[21] US Energy Information Administration (EIA). 2015. "Annual Energy Outlook 2015 With Projections to 2040.” Accessed August 25, 2016. http://www.eia.gov/forecasts/aeo/pdf/0383(2015).pdf.

[22] US Energy Information Administration (EIA). 2015. "What Is US Electricity Generation by Energy Source 2015?” Accessed May 27, 2016. https://www.eia.gov/tools/faqs/faq.cfm?id=427\&t=3.

[23] Weitz, N., Huber-Lee, A., Nilsson, M., Davis, M., and Hoff, H. 2014. "Cross-Sectoral Integration in the Sustainable Development Goals: A Nexus Approach.” Stockholm Environment Institute (SEI) Discussion Paper.

[24] Pasqual, J., Lardizabal, C., Herrera, G., Bollmann, H., and Nunes, E. "Water-Energy-Food Nexus: Comparative Scenarios and Public Policy Perspectives from Some Latin American Countries Regarding Biogas from Agriculture and Livestock.” Journal of Agricultural Science and Technology A 5 (6): 408-27.

[25] Energy Research Company (EPE). 2014. “Energy Utilization of Waste in the Context of National Energy Planning.” Accessed May 26, 2016. http://www.ahkbrasilien.com.br/fileadmin/ahk_brasilien/ portugiesische_seite/departamentos/Meio_Ambiente/Foru m_Brasil-Alemanha/Aproveitamento_Energetico_de_Res iduos_no_Contexto_do_Planejamento_Energetico_Nacio nal_0409.pdf.

[26] International Center of Renewable Energies-Biogas (CIBiogás). 2016. “Biogas Projects.” Accessed May 26, 2016. https://cibiogas.org/quem_somos. 

and the United States by 2050

[27] National Agency of Petroleum (ANP). 2015. Natural Gas and Biofuels No. 16/2008 and No. 08.

[28] American Biogas Council. 2015. "State of the Biogas US Industry.” Accessed July 24, 2016. http://americanbiogascouncil.org/pdf/ABC-StateoftheIndBiocyclePolicyPres.pdf.

[29] Murray, B. C., Galik, C. S., and Vegh, T. 2014. Biogas in the United States: An Assessment of Market Potential in a
Carbon-Constrained Future. Nicholas Institute Report, Nicholas Institute for Environmental Policy Solutions.

[30] World Bank. 2007. "Closing the Electricity Supply-Demand Gap.” Energy and Mining Sector Board Dscussion Paper No. 20. Accessed June 08, 2016. http://siteresources.worldbank.org/EXTENERGY/Resour ces/336805-1156971270190/EnergyandMiningSectorBoa rdPaperNo20.pdf. 